\title{
FAKTOR-FAKTOR YANG MEMPENGARUHI PELAKSANAAN TUGAS POKOK GURU (Studi pada MA Al Muttaquun Wates)
}

Desi Kristanti

Dosen Fakultas Ekonomi Universitas Kadiri

\begin{abstract}
Abstrak
Pada kenyataannya pelaksanaan tugas pokok guru di MAAl Muttaquun Wates Kediri adalah baik.

a. Terjadinya peningkatan kinerja guru.yang ditunjukkan dengan peningkatan jumlah rata-rata NEM lulusan siswa 2008/2009, dan 2009/2010.

b. Keberhasilan peserta EBTA/EBTANAS pada tahun pelajaran 2008/2009 sampai dengan 2010/2011.

c. Keberhasilan penjaringan UMPTN dan PMDK pada tahun pelajaran 2008/2009 sampai dengan 2010/2011.

d. Keberhasilan pelaksanaan kegiatan esktrakurikuler.

Ditemukan sejumlah faktor dalam pelaksanaan tugas pokok guru di MA Al Muttaquun Wates Kediri.

a. Belum lengkapnya sarana dan prasarana di MA Al Muttaquun Wates Kediri.

b. Para guru mengalami kesulitan dalam menemukan metode-metode mengajar yang tepat bagi para siswa.

c. Para guru mengalami kesulitan dalam membimbing kegiatan belajar siswa.

d. Para guru mengalami kesulitan untuk menanamkan motivasi pada diri siswa.

e. Para guru merasa kekurangan waktu untuk melaksanakan tugas yang telah direncanakan.

Hasil penelitian yang sudah di lakukan menunjukkan data bahwa faktor-faktor sarana dan prasarana, metode mengajar,kesulitan membimbing,kesilitan menanamkan motivasi .kesediaan waktu mempengaruhi tugas pokok guru di MA Al Muttaquun Wates
\end{abstract}

Kata kunci : Pelaksanaan tugas guru.

\section{PENDAHULUAN}

Faktor yang mempengaruhi pengelolaan dan pengembangan dunia pendidikan yang harus diperhitungkan, antara lain (1) laju perubahan cepat dan penuh tantangan, (2) tuntutan masyarakat yang lebih maju, (3) kehidupan yang sangat dipengaruhi oleh perkembangan ilmu pengetahuan, teknologi dan seni, (4) arus globalisasi dalam berbagai bentuk

Pada setiap guru terletak satu pertanggungjawaban untuk membawa murid-muridnya pada satu taraf kematangan tertentu. Apabila seorang guru mendapat kepercayaan untuk 
mengambil keputusan yang bersifat normatif, keputusan-keputusan itu dipandang sebagai penjelmaan filsafat hidup yang dianutnya. Selanjutnya guru di sekolah yang memiliki berbagai tingkatan pendidikan dan jenjang kepangkatan atau golongan mempunyai hak dan kewajiban yang relatif sama. Sedang tingginya pendidikan dan tingginya pangkat cenderung mempunyai nilai kepuasan tersendiri dan membentuk perilaku yang berbeda berdasarkan perbedaan pendidikan dan pangkat yang dimilikinya. Guru sebagai salah satu komponennya sangat menentukan keberhasilan proses pendidikan, karena mereka terlibat langsung di dalamnya. Hal mana dapat ditilik melalui tugas dan peranan guru yaitu sebagai komunikator, fasilitator dan motivator bagi para muridnya.

Peranan guru dianggap kurang utama atau kurang dinamis walaupun kegiatan mengajar dan mendidik dipandang sangat vital. Kurang urgen dan kurang dinamis ini yang menyebabkan masyarakat kurang memberikan respon pada guru.

\section{Kerangka Berpikir}

Dalam dunia pendidikan khususnya pada dunia sekolah sangatlah penting posisi tenaga pengajar, yaitu profesi guru terhadap keberhasilan pada anak didiknya. Hal tersebut dapat digambarkan sebagai berikut :

\section{Hipotesis}

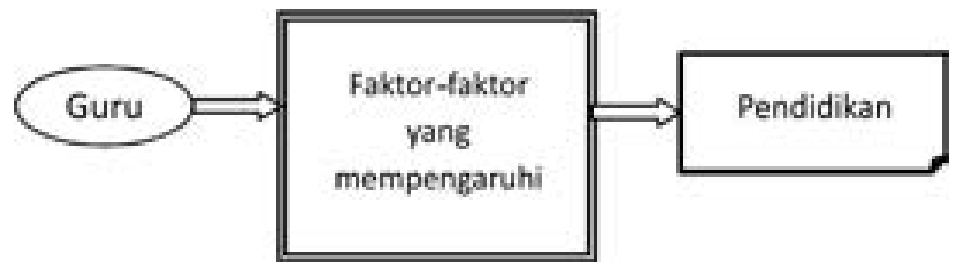

Dari latar belakang ,rumusan masalah penelitian,akhirnya penulis dapat mengambil suatu hipotesis yaitu :

1. Ada tugas pokok guru yang dilaksanakan oleh guru MAAl Muttaquun Wates Kediri

2. Ada faktor yang mempengaruhi tugas pokok pada guru MAAl Muttaquun Wates

\section{METODOGI PENELITIAN}

\section{Jenis Penelitian}

Jenis penelitian yang digunakan sesuai dengan maksud penelitian adalah :

a Daftar pertanyaan yang ditujukan kepada para guru tentang pelaksanaan tugas pokok guru.

b. Daftar pertanyaan yang ditujukan kepada para guru tentang faktor-faktor yang mempengaruhi pelaksanaan tugas pokok guru.

c. Alat ukur dari pelaksanaan tugas pokok guru dan faktor-faktor yang mempengaruhi tugas pokok guru.

\section{Metode Pengumpulan Data}

Yang dimaksud dengan metode pengumpulan data adalah cara yang dipergunakan untuk mencari dan mengumpulkan data yang diperlukan. Dalam melaksanakan penelitian ini digunakan beberapa metode pengumpulan data, antara lain: 
a. Observasi

Yaitu penelitian yang dilakukan dengan mengadakan pengamatan dan pencatatan secara sistematik terhadap obyek yang diteliti. Metode observasi bertujuan untuk membantu responden menjawab pertanyaan disamping itu untuk mengecek jawaban responden.

b. Questionery

Yaitu memberikan serangkaian pertanyaan melalui angket pada responden, dalam hal ini adalah seluruh guru MA Al Muttaquun Wates Kediri.

c. Studi kepustakaan / Literatur

Yaitu mengumpulkan data dari buku literature, dokumen dan sebagainya yang berhubungan dengan pokok permasalahan.

\section{Analisa data}

Setelah data yang diperlukan sudah terkumpul dan telah dikelompokkan menurut tujuan dan kebutuhannya, maka langkah yang diambil adalah menganalisa data tersebut.

Dengan memperhatikan tujuan dalam penelitian, metode analisa yang dipakai adalah metode analisa deskriptif. Penelitian deskriptif merupakan penelitian yang bertujuan untuk mencari gambaran atau ingin menggambarkan tentang suatu keadaan fenomena. Penelitian disekriptif ini dapat digolongkan kedalam penelitian non hipotesis.

\section{HASIL DAN PEMBAHASAN}

Organisasi dan manajemen MA Al Muttaquun Wates Kediri disesuaikan dengan kebutuhan untuk mencapai tujuan pendidikan menengah umum. Pelaksanaannya menjadi tanggung jawab Kepala Sekolah dan Tenaga Kependidikan lainnya sesuai peran dan fungsinya masing-masing. Untuk dijabarkan tentang pembagian tugas dan tanggung jawab yang proposional dan diciptakan iklim kerja yang kondusip, dengan struktur organisasi dan pembagian tugas dan wewenang.

\section{Kondisi Obyektif Sekolah}

\section{Guru, Siswa dan Karyawan}

Pada tahun pelajaran 2010/2011 keadaan MA Al Muttaquun Wates Kabupaten Kediri adalah sebagai berikut :

a. Guru

Tabel 1 : Data Guru MA Al Muttaquun Wates Kediri

\begin{tabular}{|c|c|c|c|c|c|}
\hline Pendidikan & GTT & GTT/PNS & Pria & Wanita & Jumlah \\
\hline S-1 & 19 & 21 & 20 & 20 & 40 \\
\hline S-2 & - & 3 & 1 & 2 & 3 \\
\hline Jumlah & 19 & 24 & 21 & 22 & 43 \\
\hline
\end{tabular}

Sumber : MA Al Muttaquun Wates Kediri 


\section{Perkembangan dan Pertumbuhan Guru}

Perkembangan teknologi serta tuntutan perubahan kurikulum pendidikan MA Al Muttaquun Wates Kediri dirasa perlu memberikan penyegaran kepada guru mata pelajaran mengikuti kegiatan berupa seminar, penataran, MGMP, Diklat dan memberikan kesempatan mengajar, hal ini dimaksudkan untuk mengimbangi tuntutan perubahan yang ada, adapun data fisiknya adalah sebagai berikut :

a. Kegiatan Seminar

Tabel 2 : Kegiatan Seminar

\begin{tabular}{|c|c|c|c|c|c|}
\hline \multirow{2}{*}{ No. } & \multirow{2}{*}{ Nama } & \multirow{2}{*}{ Jenis Seminar } & \multicolumn{3}{|c|}{ Tahun } \\
\hline & & & 2009 & 2010 & 2011 \\
\hline 1 & Eko Dody P., S.Pd & Pengembangan KTSP & & $\ddot{u}$ & ü \\
\hline 2 & Siti Maro'ah, S.Pd, M.Pd & Pengembangan KTSP & & ü & ü \\
\hline 3 & Ayu Dini A., S.Pd & Penelusuran Bakat \& Minat Siswa & $\ddot{u}$ & & \\
\hline 4 & Drs. Agus Wahono & Pembelajaran dengan pendekatan CTL & & $\ddot{u}$ & \\
\hline 5 & Dra. Nurul Hasanah & Pembelajaran dengan pendekatan CTL & & $\ddot{u}$ & \\
\hline 6 & Reni Yuliasih, S.Pd & Pembelajaran dengan pendekatan CTL & & $\ddot{u}$ & \\
\hline
\end{tabular}

\section{Sumber : MA Al Muttaquun Wates Kediri}

b. Perkembangan Jenjang Pendidikan Guru

Tabel 3: Perkembangan Jenjang Pendidikan Guru MA Al Muttaquun Wates

\begin{tabular}{|c|c|c|c|c|c|c|}
\hline \multirow{2}{*}{ No } & \multirow{2}{*}{ Pendidikan Terakhir } & \multicolumn{4}{|c|}{ TAHUN } & \multirow{2}{*}{ Ket. } \\
\cline { 3 - 6 } & & 2008 & 2009 & 2010 & 2011 & \\
\hline 1 & Strata 1 & 32 & 37 & 38 & 38 & \\
\hline 2 & Strata 2 & & 1 & 3 & 3 & \\
\hline
\end{tabular}

Sumber : MA Al Muttaquun Wates Kediri

Keterangan :

Berkurangnya tenaga pendidik yang lulusan S1 dikarenakan melanjutkan ke pendidikan yang lebih tinggi yaitu S2, dengan demikian harapan pada akhirnya yang mengajar di MA Al Muttaquun Wates Kediri semua pendidik adalah lulusan S1 / Sarjana.

\section{Perkembangan Prosentase Kinerja Guru/Karyawan}

Tabel 4 : Perkembangan Kinerja Guru MA Al Muttaquun Wates

\begin{tabular}{|c|l|c|c|c|c|}
\hline \multirow{2}{*}{ No } & \multicolumn{2}{|c|}{ Uraian } & \multicolumn{4}{c|}{ TAHUN } \\
\cline { 3 - 6 } & & 2008 & 2009 & 2010 & 2011 \\
\hline 1. & Rata-rata kehadiran guru & 82,5 & 87,6 & 90,6 & 91,8 \\
\hline 2. & Guru yang membuat perangkat mengajar lengkap & 85,1 & 92,3 & 91,2 & 95,8 \\
\hline 3. & Guru yang melaksanakan evaluasi & 100 & 100 & 100 & 100 \\
\hline 4. & Guru yang membuat analisa hasil evaluasi & 84,4 & 85,2 & 88,9 & 90,3 \\
\hline 5. & $\begin{array}{l}\text { Guru yang membuat program perbaikan dan } \\
\text { pengayaan }\end{array}$ & 82,9 & 84,3 & 86,2 & 89,8 \\
\hline 6. & Rata-rata kehadiran TU & 90 & 91,3 & 92,3 & 95,3 \\
\hline
\end{tabular}

Sumber : MA Al Muttaquun Wates Kediri 
Keterangan :

a Kehadiran guru masih belum bisa sepenuhnya memenuhi jadwal yang dibuat sekolah. Walaupun sudah diatur sedemikian rupa dengan pertimbangan kegiatan masing-masing guru yang ada.

b. Guru yang membuat perangkat mengajar disamping belum lengkap masih ada yang menggunakan perangkat mengajar tahun yang lalu atau hasil MGMP yang seharusnya perlu penyesuaian dengan tuntutan perkembangan yang ada.

c. Secara nyata semua guru sudah melaksanakan evaluasi dengan dibuktikan pada Daftar Kumpulan Nilai (DKN) pada masing-masing guru pelajaran.

d. Guru yang membuat analisa hasil evaluasi untuk mengetahui tingkat ketuntasan belajar siswa masing-masing pelajaran masih perlu peningkatan dan motivasi.

e. Guru yang membuat program perbaikan dan pengayaan masih perlu ditingkatkan atau digalakkan.

f. Secara umum kehadiran karyawan / TU sudah memuaskan tetapi masih perlu adanya pembinaan dan motivasi secara terus menerus.

\section{Tabel 5 :Pelaksanaan tugas pokok guru dewasa (III/b) dan guru dewasa tinggkat I} (III/d) MA Al Muttaquun Wates Kediri

\begin{tabular}{|c|c|c|c|c|c|}
\hline \multirow{2}{*}{ No } & \multirow{2}{*}{ Uraian } & \multicolumn{4}{|c|}{ TAHUN } \\
\hline & & 2008 & 2009 & 2010 & 2011 \\
\hline 1. & $\begin{array}{l}\text { Melaksanakan penyusunan program pengajaran (Silabus, Rencana } \\
\text { pelaksanaan pembelajaran/Rpp. Program tahunan IPROTA, } \\
\text { Program Semester/PROMES) praktik, bimbingan ataukonseling }\end{array}$ & 100 & 100 & 100 & 100 \\
\hline 2. & $\begin{array}{l}\text { Melaksanakan penyajian program pengajaran kegiatan tatap muka } \\
\text { (Kegiatan penyampaian materi pelajaran. Membimbing melatih } \\
\text { peserta didik terkait dengan materi pelajaran. Menilai hasil belajar } \\
\text { yang terintegrasi), praktik bimbingan atau konseling }\end{array}$ & 100 & 100 & 100 & 100 \\
\hline 3. & $\begin{array}{l}\text { Melaksanakan evaluasi belajar atau praktek (dalam bentuk dattar } \\
\text { nilai } 11 \text { pelajaran), pelaksanaan bimbingan dan konseling }\end{array}$ & 100 & 100 & 100 & 100 \\
\hline 4. & $\begin{array}{l}\text { Melaksanakan analisa hasil evaluasi belajar (Daftar nilai rapot siswa) } \\
\text { atau praktek atau pelaksanaan bimbingan konseling }\end{array}$ & 100 & 100 & 100 & 100 \\
\hline 5. & $\begin{array}{l}\text { Menyusun dan melaksanakan program perbaikan (Perbaikan dan } \\
\text { pengayaan) dan pengayaan atau tindak lanjut bimbingan dan } \\
\text { konseling. }\end{array}$ & 82,9 & 84,3 & 86,2 & 89,8 \\
\hline 6. & $\begin{array}{l}\text { Membimbing siswa (khusus guru yang memegang kegiatan } \\
\text { ekstrakurikuler berupa (Pramuka, Lomba kompetisi siswa, Clagraga- } \\
\text { Pecinta alam-Palang Merah Remaja-Unit Kesehatan Sekolah (UKS) }\end{array}$ & 62,3 & 66,5 & 70.2 & 72,6 \\
\hline
\end{tabular}

Sumber : MA Al Muttaquun Wates Kediri 
Keterangan :

1. Guru yang membuat perangkat mengajar disamping belum lengkap masih ada yang menggunakan perangkat mengajar tahun yang lalu atau hasil MGMP yang seharusnya perlu penyesuaian dengan tuntutan perkembangan yang ada.

2. Guru menyampaikan materi pelajaran,membimbing,melatih peserta didik terkait dengan materi dan menilai hasil belajar

3. Secara nyata semua guru sudah melaksanakan evaluasi dengan dibuktikan pada Daftar Kumpulan Nilai (DKN) pada masing-masing guru pelajaran.

4. Guru yang membuat analisa hasil evaluasi untuk mengetahui tingkat ketuntasan belajar siswa masing-masing pelajaran masih perlu peningkatan dan motivasi

5. Guru yang membuat program perbaikan dan pengayaan masih perlu ditingkatkan atau digalakkan.

6. Guru yang memegang kegiatan ekstrakurikuler

\section{Perkembangan Sarana dan Prasarana}

Sarana adalah segala sesuatu yang disebut sebagai alat dalam mencapai tujuan pendidikan, sedangkan prasarana adalah segala sesuatu yang merupakan penunjang terselenggaranya proses pendidikan. Perkembangan dan pertumbuhan sarana dan prasarana adalah sebagai berikut :

\section{Tabel 6: Perkembangan Sarana dan Prasarana MA Al Muttaquun Wates}

\begin{tabular}{|c|c|c|c|c|c|}
\hline \multirow{2}{*}{ No } & \multirow{2}{*}{$\begin{array}{l}\text { Sarana dan } \\
\text { Prasarana }\end{array}$} & \multicolumn{4}{|c|}{ TAHUN } \\
\hline & & 2000 & 2009 & 2010 & 2011 \\
\hline \multirow[t]{13}{*}{ t. } & Ruengan & & & & \\
\hline & Kolas & 7 & 7 & 9 & 9 \\
\hline & Popustian & $=$ & 1 & 1 & 1 \\
\hline & Raurg Kegala Sacich & $t$ & 1 & $t$ & 1 \\
\hline & Tats Unats & $t$ & , & 1 & 1 \\
\hline & Gun & 1 & 1 & 1 & 1 \\
\hline & BX & . & 1 & 1 & 1 \\
\hline & Kogens & - & - & - & $t$ \\
\hline & Gutang & 1 & 1 & $t$ & 1 \\
\hline & Labcriesnm IPA &. &. & 1 & $t$ \\
\hline & Inboratorim Batises & + & . & - & - \\
\hline & Komouter & 4 & 15 & 15 & 15 \\
\hline & Prance & * & . & 1 & 1 \\
\hline \multirow[t]{4}{*}{2.} & Kans KedilWC & & & & \\
\hline & Sswa & 32 & 33 & 33 & 30 \\
\hline & Qun & 3 & 3 & 3 & 3 \\
\hline & Kegala Seloliah & $t$ & 1 & 1 & 1 \\
\hline 3. & Mrshola & 1 & $t$ & 1 & 1 \\
\hline \multirow[t]{4}{*}{4} & Thenos! Pare & & & & \\
\hline & Ssoa & 1 & $t$ & 1 & 1 \\
\hline & Qun & 1 & 1 & 1 & 1 \\
\hline & Kepala Selodah & 1 & 1 & 1 & 1 \\
\hline 5. & Pagar Solowan & 1 & 1 & 1 & 1 \\
\hline
\end{tabular}

\begin{tabular}{|c|c|c|c|c|c|}
\hline \multirow{2}{*}{ No } & \multirow{2}{*}{$\begin{array}{l}\text { Sarana dan } \\
\text { Prasarana }\end{array}$} & \multicolumn{4}{|c|}{ TAHUN } \\
\hline & & 2008 & 2009 & 2010 & 2011 \\
\hline 6. & Lapingan Upacaa & 1 & 1 & 1 & 1 \\
\hline 7. & Jian Seloiah & 3spas & aspal & aspal & aspa \\
\hline \multirow[t]{3}{*}{8.} & Lapingn Ostrapa & & & & \\
\hline & Pernairan & . & 1 & 1 & 1 \\
\hline & Asetk & - & 1 & 1 & 1 \\
\hline 9. & Kantn Selolah & 2 & 3 & 3 & 3 \\
\hline 10. & Meja Pariang & 175 & 175 & 175 & 175 \\
\hline 11. & Meja Pendek & r & • & 100 & 100 \\
\hline 12. & Kunsi Paging & * & $\cdot$ & $\cdot$ & $\cdot$ \\
\hline 13. & Kursi Pendek & 350 & 350 & 450 & 450 \\
\hline
\end{tabular}

Sumber : MA Al Muttaquun Wates Kediri 
Terjadinya penambahan sarana dan prasarana yang ada dimaksudkan guna melengkapi tuntutan kebutuhan yang mendesak dan tidak dapat ditunda lagi dari jumlah siswa terhadap idealnya sarana yang harus disediakan.

\section{Tabel 7 : Metode Pengajaran}

\begin{tabular}{|l|l|c}
\hline No. & Metode Pengajaran & Pelaksanaan (\%) \\
\hline 1. & Pemberian tugas & 100 \\
\hline 2. & Diskusi & 100 \\
\hline 3. & Ceramah & 100 \\
\hline 4. & Tanya Jawab & 100 \\
\hline 5. & Metode bermain & 20 \\
\hline 6. & Informasi & 100 \\
\hline
\end{tabular}

Sumber : MA Al Muttaquun Wates Kediri

Tabel 8 : Guru mengalami kesulitan dalam membimbing kegiatan belajar siswa

\begin{tabular}{|l|l|}
\hline No. & \multicolumn{1}{|c|}{ Meningkatkan motivasi guru } \\
\hline 1 & $\begin{array}{l}\text { Pemberian rewaed terhadap prestasi guru dalam meningkatkan proses belajar } \\
\text { mengajar yang di lakukan setiap periodik } \\
\text {-Memberikan sertifikat } \\
\text {-Memberikan dorpres /hadiah }\end{array}$ \\
\hline
\end{tabular}

Sumber : MA Al Muttaquun Wates Kediri

Tabel 9 : Motivasi terhadap siswa

\begin{tabular}{|l|l|c|}
\hline NO & \multicolumn{1}{|c|}{ Motivasi terhadap siswa } & Frekuensi \\
\hline 1 & $\begin{array}{l}\text { Memberikan rewaed terhadap siswa yang berprestasi:berupa bea siswa } \\
\text { dan hadiah }\end{array}$ & 2X / Lebih \\
\hline
\end{tabular}

Sumber : MA Al Muttaquun Wates Kediri

\section{Keterangan :}

Pemberian hadiah, bea siswa diberikan $2 \mathrm{X}$ dalam setahun dilakukan sebagai hasil evaluasi nilai UAS siswa yang tertinggi.Kegiatani ini dilakukan agar memberikan semangat siswa mendapat nilai tinggi pada mata pelajaran yang ditempuh

\section{Tabel 10:Kurangnya waktu dalam perencanaan}

\begin{tabular}{|l|l|l|}
\hline NO & Pelaksanaan waktu pembelajaran masing-masing guru & $\begin{array}{l}\text { Jumlah guru yang melakukan } \\
\text { diatas jam ketentuan }\end{array}$ \\
\hline 1 & $\begin{array}{l}\text { Guru merasa kurang waktu dalam melaksanakan tugas } \\
\text { yang di rencanakan: } \\
\text {-Waktu yang di tentukan 45 menit } \\
\text {-Mengerjakan tugas }>45 \text { menit }\end{array}$ & $50,4 \%$ \\
\hline
\end{tabular}

Sumber : MA Al Muttaquun Wates Kediri 


\section{Keterangan :}

Dalam pelaksanaan pembelajaran tidak semua guru melakukan kurangnya waktu pengajaran.pelajaran yang membutuhkan waktu pengajaran di atas jam ketentuan yaitu mata pelajaran : Matematika,Bahasa inggris,Bahasa indonesia,Akuntansi sebanyak 50,4\%

\section{Analis Pelaksanaan Tugas Pokok Guru di MA Al Muttaquun Wates Kediri}

Kondisi obyektif dari pelaksanaan tugas pokok guru di MA Al Muttaquun Wates Kediri, dalam hal ini para guru tetap yang berjumlah 24 orang (sesuai dengan sample) yang memiliki golongan ruang IIIa sebanyak 16 orang, IIIb sebanyak 5 orang, IIId sebanyak 1 orang dan IVa sebanyak 2 orang sebagai Guru Dewasa Tingkat I, Guru Dewasa, Guru Madya Tingkat I, dan Guru Madya menunjukkan hasil yang baik.

Bila kita bandingkan seorang guru yang pandai dan mampu mengajar, kemudian dibandingkan dengan guru yang tidak cekatan, yang kita lakukan sebenarnya telah membandingkan sifat-sifat profesional tertentu antara kedua orang itu. Tentu saja masingmasing dari kita dapat membandingkan seorang guru dengan guru lainnya untuk menaril pelajaran apakah sebab guru yang seorang lebih berhasil dari usahanya sedangkan guru yang lain tidak. Didalam membandingkan iti sudah jelas bahwa kita harus memiliki sejumlah criteria yang diperlukan sebagai titik pegangan. Tanpa criteria itu kita mudah terpengaruh oleh sifatsifat yang tidak fundamental atau oleh faktor-faktor situasional. Disamping kebutuhan untuk dapat menilai efisiensi seorang guru didalam tugasnya sehari-hari, terdapat kebutuhan yang lebih penting untuk dapat menilai efisiensi diri sendiri sebagai seorang guru. Karena tugas seorang guru adalah tugas yang langsung menyangkut kepentingan siswa khususnya dan dunia pendidikan pada umumnya, maka sudah sepatutnyalah apabila efisiensi usaha seorang guru tidak hanya ditinjau dari sudut guru itu sendiri, tetapi perlu melihat aspek yang lain.

Keberhasilan pelaksanaan tugas pokok guru di MA Al Muttaquun Wates Kediri ini terlihat dari beberapa hal sebagai berikut :

\section{1) Perkembangan Kinerja Guru di MA Al Muttaquun Wates Kediri}

Terjadinya peningkatan kinerja guru (dijelaskan dalam bab III. Tabel 3.10) dalam empat tahun terakhir dari tahun 2008/2009 sampai dengan tahun 2010/2011, secara rinci berdasarkan kuesioner yang telah disebarkan dan observasi yang telah penulis lakukan, tugas pokok yang dibebankan pada guru sesuai dengan Golongan Ruang dan Jabatannya, adalah sebagai berikut :

a. Pelaksanaan Tugas Pokok Guru Madya (III/a) dan Guru Madya Tingkat I (III/b), adalah sebagai berikut :

Pada penelitian ini jumlah Guru Madya (III/a) adalah 16 orang dan jumlah Guru Madya Tingkat I (III/b) adalah 5 orang. Jadi jumlah keseluruhan guru pada katagori ini adalah 21 orang. Uraian pelaksanaan tugas pokok guru di MA Al Muttaquun Wates Kediri adalah sebagai berikut :

1. Melaksanakan penyusunan program pengajaran atau praktik atau bimbingan dan konseling.

Pada kenyataannya semua guru di MA Al Muttaquun Wates Kediri telah menyusun program pengajaran, praktik, bimbingan dan konseling. Dari jumlah guru tetap dan kategori ini yang berjumlah 14 orang $100 \%$ telah melakukan tugas pokok tersebut. 
3. Melaksanakan penyajian program pengajaran atau praktik atau bimbingan dan konsling.

Pada kenyataannya sekitar 78,57\% atau 11 orang di MA Al Muttaquun Wates Kediri telah melaksanakan Penyajian program pengajaran, praktik, bimbingan dan konseling.

4. Melaksanakan evaluasi belajar atau praktik atau pelaksanaan bimbingan dan konseling.

Berdasarkan hasil angket $100 \%$ guru di MAAl Muttaquun Wates Kediri telahmelaksanakan evaluasi, hal ini dapat dibuktikan pada Daftar Kumpulan Nilai pada masing-masing guru mata pelajaran.

5. Melaksanakan analisa hasil evaluasi belajar praktik atau pelaksanaan bimbingan dan konseling.

Pada pelaksanaannya $100 \%$ guru di MA Al Muttaquun Wates Kediri telah melaksanakan analisa hasil evaluasi, yang dapat dibuktikan dari tersusunya Daftar Nilai Raport masing-masing siswa sehingga masing-masing guru dapat membuat analisa prestasi siswa dari evaluasi yang telah dilakukan.

6. Menyusun dan melaksanakan program perbaikan dan pengayaan atau tindak lanjut bimbingan dan konseling.

Hasil angket dan observasi menyebutkan bahwa $70 \%$ guru atau sekitar 7 orang guru di MA Al Muttaquun Wates Kediri telah menyusun dan melaksanakan program perbaikan dan pengayaan atau tindak lanjut bimbingan dan konseling. Hal ini terbukti dari dilaksanakan ujian ulang bagi siswa yang mempunyai nilai dibawah standar.

7. Membimbing Siswa (khusus guru yang memegang kegiatan ekstrakurikuler) dalam kegiatan ekstrakurikuler.

Pada dasarnya semua sebagian guru di MA Al Muttaquun Wates Kediri telah melakukan bimbingan dan pengarahan siswa dalam kegiatan ekstrakurikuler. Dari jumlah guru yang ada sekitar 50\% atau sekitar 7 orang telah melaksanakan tugas tersebut. Hal ini terlihat dari keberhasilan yang dicapai siswa dalam kegiatan ekstra kurikuler baik tingkat Kecamatan, Kabupaten, Propinsi dan Nasional.

b. Pelaksanaan Tugas Pokok Guru Dewasa (III/c) dan Guru Dewasa Tingkat I (IV/a), adalah sebagai berikut :

Dalam hal ini jumlah Guru Dewasa (III/c) adalah 1 orang dan jumlah Guru Dewasa Tingkat I (IV/a) adalah 2 orang. Jadi jumlah keseluruhan guru dalam kategori ini adalah 3 orang. Uraian pelaksanaan tugas pokoknya di MA Al Muttaquun Wates Kediri adalah sebagai berikut :

1. Melaksanakan penyusunan bahan ajar.

Dari jumlah Guru Dewasa dan Guru Dewasa Tingkat I 100\% atau 3 orang guru di MA Al Muttaquun Wates Kediri telah melakukan penyusunan program pengajaran praktik, bimbingan dan konseling.

2. Melaksanakan penyajian program pengajaran atau praktik atau pelaksanaan bimbingan dan konseling. 
Dari jumlah guru yang ada ternyata sudah semuanya melaksanakan penyajian program pengajaran atau praktik dan bimbingan serta konseling.

3. Melakukan evaluasi terhadap proses belajar mengajar,pelaksanaan bimbingan konseling.Pada hakekatnya semua guru di MA Al Muttaquun Wates Kediri atau 100\% . Evaluasi ini dilakukan dalam bentuk ulangan harian, ulangan Catur Wulan maupun melalui pemberian tugas bagi siswa setelah Proses Belajar Mengajar selesai.

4. Melaksanakan analisa terhadap evaluasi yang dilakukan baik pada proses belajar mengajar,praktik atau pelaksanaan bimbingan dan konseling

Dari jumlah Guru Dewasa dan Guru Dewasa Tingkat I 100\% para guru di MA Al Muttaquun Wates Kediri.Karena hal ini merupakan tindak lanjut dari evaluasi yang telah dilakukan, untuk memberikan suatu keputusan tentang berhasil tidaknya seorang siswa dalam Proses Belajar Mengajar.

5. Melakukan program perbaikan dan pengayaan dan belum melakukan tindaka lanjut atas bimbingan dan konseling yang telah di lakukan.

Dari hasil analisa data hanya 74,16\% atau sekitar 19 orang guru di MA Al Muttaquun Wates Kediri.Tindak lanjut dari program perbaikan dan pengayaan ini adalah bentuk pelaksanaan ulangan perbaikan atau pemberian tugas untuk menambah nilai siswa yang masih kurang.

6. Membimbing siswa dalam kegiatan ektra kurikuler

Dari keberhasilan siswa dalam kegiatan ektrakurikuler baik ditingkat Kecamatan, Kabupaten, Propinsi maupun Nasional, hal ini telah merupakan bukti bahwa sebagian guru di MA Al Muttaquun Wates Kediri telah melakukan bimbingan pada para siswa dalam kegiatan ektra kurikuler. Dari jumlah Guru Dewasa dan Guru Dewasa Tingkat I sekitar 54,17\% atau 13 orang saja yang melakukan tugas tersebut. Hal ini dikarenakan hanya guru yang berkaitan dengan kegiatan ektrskurikuler saja yang melakukan bimbingan dan pengarahan pada siswa.

7. Melaksanakan bimbingan dalam kegiatan proses belajar mengajar atau praktek atau bimbingan dan konseling

Dari jumlah guru dewasa dan guru dewasa tingkat I di MA Al Muttaquun Wates, belum semua guru melaksanakan tugas tersebut. Hanya 37,5\% atau 9 orang saja yang melaksanakan tersebut. Hal ini terjadi karena hanya para guru yang mengalami kesulitan atau permasalahan dalam proses belajar mengajar yang mengadu pada guru yang lain tentang kesulitan yang mereka alami. Karena alas an ini maka belum semua guru melaksanakan tugas tersebut.

8. Melaksanakan bimbingan dalam pelaksanaan pelajaran tambahan ( LES ) Khusus nya bidang studi yang di ebtanaskan.

Dari sejumlah guru yang ada pada kenyataannya $100 \%$ guru di MA Al Muttaquun 
Wates telah melakukan bimbingan dalam kegiatan evaluasi belajar tahap akhir atau evaluasi belajar tahap akhir nasional.Hal ini terbukti dari keberhasilan siswa dalam kelulusan, yaitu kelulusan yang dicapai adalah $100 \%$, juga terlihat dari peningkatan rata-rata NEM lulusan dalam tiga tahun terakhir.

\section{Analisa Faktor-Faktor Yang Menghambat PelakSanaan Tugas Pokok Guru}

Pada perjalanan selanjutnya pelaksanaan tugas pokok guru tidak terlepas dari faktor- faktor yang menghambat yang selalu ada. Begitu juga pelaksanaan tugas pokok guru di MA Al Muttaquun Wates Kediri tidak terlepas dari faktor-faktor penghambat, adapun yang menjadi faktor penghambat adalah :

1. Belum lengkapnya sarana dan prasarana yang dimiliki oleh MA Al Muttaquun Wates Kediri.

2. Para guru mengalami kesulitan dalam menemukan metode-metode mengajar yang tepat bagi para siswa.

Metode mengajar banyak sekali ragam dan jenisnya, disebabkan oleh karena metode ini dipengaruhi banyak faktor, yaitu :

a. Tujuan yang berbeda masing - masing kompetensi dasar.

b. Anak didik yang berbeda tingkat kematangannya.

c. Situasi yang berbeda-beda.

d. Fasilitas yang berbeda baik kualitas maupun kwantitasnya.

e. Pribadi guru serta kemampuan professional yang berbeda.

3. Para guru mengalami kesulitan dalam membimbing kegiatan belajar siswa.

4. Para guru mengalami kesulitan untuk menanamkan motivasi pada diri siswa.

5. Para guru merasa kekurangan waktu untuk melaksanakan apa yang telah direncanakan.

Bagi seorang guru akan bermanfaat semaksimal mungkin sesuai dengan target yang telah ditetapkan

a. Masa Persiapan

1. Persiapan terhadap situasi umum.

2. Persiapan terhadap murid yang dihadapi.

3. Persiapan dalam tujuan yang dicapai.

4. Persiapan terhadap bahan yang diajarkan.

5. Persiapan dalam metode mengajar.

6. Persiapan dalam alat-alat pembantu.

7. Persiapan dalam teknik-teknik evaluasi.

b. Masa Pelaksanaan

Setelah masa persiapan dilaksanakan, langkah selanjutnya adalah pelaksanaan dari apa yang telah direncanakan. Beberapa hal yang dapat dikemukakan sebagai solusi operasional oleh masing-masing guru di MA Al Muttaquun Wates Kediri adalah 
sebagai berikut :

1. Pemberian Insentif (reward)

2. Program pengadaan intrumen dalam Proses Belajar Mengajar.

3. Memberikan kesempatan untuk mengikuti diklat profesional bagi

4. Pemenuhan sarana dan prasarana yang sangat mendukung guru dalam proses belajar mengajar.

\section{KESIMPULAN DAN SARAN}

\section{A. Kesimpulan}

1. Pada kenyataannya pelaksanaan tugas pokok guru di MAAl Muttaquun Wates Kediri adalah baik.

a. Terjadinya peningkatan kinerja guru.

b. Terjadinya peningkatan jumlah rata-rata NEM lulusan siswa 2008/2009, dan 2009/2010.

c. Keberhasilan peserta EBTA/EBTANAS pada tahun pelajaran 2008/2009 sampai dengan 2010/2011.

d. Keberhasilan penjaringan UMPTN dan PMDK pada tahun pelajaran 2008/2009 sampai dengan 2010/2011.

e. Keberhasilan pelaksanaan kegiatan esktrakurikuler.

2. Ditemukan sejumlah factor penghambat dalam pelaksanaan tugas pokok guru di MAAl Muttaquun Wates Kediri.

a. Belum lengkapnya sarana dan prasarana yang MA Al Muttaquun Wates Kediri.

b. Para guru mengalami kesulitan dalam menemukan metode-metode mengajar yang tepat bagi para siswa.

c. Para guru mengalami kesulitan dalam membimbing kegiatan belajar siswa.

d. Para guru mengalami kesulitan untuk menanamkan motivasi pada diri siswa.

e. Para guru merasa kekurangan waktu untuk melaksanakan apa yang telah direncanakan.

\section{B. Saran} masukkan.

Demi perbaikan selanjutnya maka berikut saran-saran yang dapat dipakai sebagai

1. Bagi Kepala Sekolah

Hendaknya lebih memperhatikan secara seksama dalam pembinaan dan pengawasan tentang pelaksanaan tugas pokok guru.

2. Bagi Para Guru

Hendaknya lebih berusaha untuk melaksanakan tugas pokoknya sesuai dengan tugas dan tanggung jawabnya baik sebagai guru kelas, guru praktek, guru pembimbing maupun 
guru mata pelajaran.

3. Bagi Departemen Agama

Untuk lebih meningkatkan perhatiannya kepada para guru dalam hal memberikan kesempatan meningkatkan pengetahuan, ketrampilan dalam profesinya sebagai guru.

4. Bagi Para Peneliti

Disadari bahwa penelitian ini masih jauh dari sempurna, banyak memiliki kekurangan dan kesalahan. Oleh karena itu disarankan bagi peneliti selanjutnya agar mengkaji lebih dalam beberapa aspek yang terkait untuk lebih memperjelas gambaran umum yang menjadi perhatian dalam penelitian ini.

\section{DAFTAR PUSTAKA}

Keputusan Menteri Negara Pendayagunaan Aparatur Negara Nomor 84 Tahun 1993

Tentang Jabatan Fungsional Guru dan angka Kreditnya

Ali Muhammad. Penelitian Kependidikan Prosedur dan Strategi. Bandung;

Angkasa,1987. Arikunto,Suharsimi.Dasar-Dasar Evaluasi Pendidikan. Jakarta;Bumi

Aksara,1992..

Burhanudin,Yusak.Administrasi Pendidikan Bandung;CV Putaka Setia,1998

Djamarah,Syaiful Bahri dan zain,Prestasi Belajar dan Kompetensi Guru.Surabaya;Usaha Nasional,1994.

Handoko Hani T.DR.MBA,tahun 1995.Manajemen Edisi 2,BPFE Yogyakarta.

Indra Fachrudi,Soekarno.Bagaimana Memimpin Sekolah yang Efisian.Bogor;Ghalia Indonesia, 2006

Imron,Ali.Pembinaan Guru di Indonesia,Jakarta;Pustaka Jaya,1995

Kusnandar,Guru Profesional Implementasi kurikulum Tingkat Satuan Pendidikan (KTSP) dan Sukses dalam Sertifikasi Guru,Jakarta,PT.Raya Grafindo Persada,2007

Keputusan Menteri Negara Perdayaan aparatur Negara Nomor 84 Tahun 1993.

Keputusan Bersama Menteri Pendidikan dan Kebudayaan dan Kepala Badan Administrasi Negara Nomor 0433/p/1993

Lazaruth,Soewadji. Kepala Sekolah dan Tanggung jawabnya. Yogyakarta; Kanisius,1984

Mulyana,E.Standar Kopetensi dan Sertifikasi Guru,Bandung,PT.Remaja

Rosdakarya,2007. Peraturan Pemerintah Nomor 19 Tahun 2005 Tentang Standar Nasional

Pendidikan Undang-Undang Nomor 14Tahun 2005 tentang Guru dan Dosen

Undang-Undang Nomor 20 Tahun 2003 Tentang Sistem Pendidikan Nasional

Usman,Moh.User.Menjadi Guru Profesional.Bandung; Remaja Rosda Karya,1990

Wahjosumidjo.Kepemimpinan Kepala Sekolah Tinjauan Teoritik dan Permasalahannya. Jakarta;PT Raja Grafindo Persada,1999. 